\title{
Participation in crimes in the jurisprudence of the ICTY and ICTR
}

Mohamed Elewa Badar

\section{Introduction}

The Statutes of the International Criminal Tribunal for the former Yugoslavia ${ }^{1}$ (ICTY) and the International Criminal Tribunal for Rwanda ${ }^{2}$ (ICTR) explicitly provide that these Tribunals are concerned with natural persons only. ${ }^{3}$ Legal entities such as associations or organizations cannot be declared criminal as such, thereby excluding membership in such entities as a legal basis for criminal responsibility. ${ }^{4}$ Articles 7(1)(3) and 6(1)(3) of the ICTY and ICTR Statutes, respectively, are the general provisions governing whether and through what mode of liability an accused may be held responsible for a crime within the jurisdiction of these Tribunals. The full text of these provisions reads as follows:

\section{Individual Criminal Responsibility}

1 A person who planned, instigated, ordered, committed or otherwise aided and abetted in the planning, preparation or execution of a crime referred to in Articles 2 to 5 of the present [ICTY] Statute [and Articles 2 to 4 of the ICTR Statute] shall be individually responsible for the crime....

2 The fact that any of the acts referred to in Articles 2 to 5 of the present Statute [and Articles 2 to 4 of the ICTR Statute] was committed by a subordinate does not relieve his or her superior of criminal responsibility if he or she knew or had reason to know that the subordinate was about to commit such acts or had done so and the superior failed to take the necessary and reasonable measures to prevent such acts or to punish the perpetrator thereof. ${ }^{5}$

The principle underlying the aforementioned provisions is that an individual is responsible for his or her acts and omissions. ${ }^{6}$ That is to say, an individual may be held criminally responsible for the direct commission of a crime, whether as an individual or jointly, ${ }^{7}$ or through his or her omissions with regard to the crimes of subordinates when under obligation to act. ${ }^{8}$ This chapter uses a systematic analysis of the Tribunals' case law to examine the subjective and objective elements of different modes of perpetration and participation in criminal conduct. 


\section{Responsibility under Articles 7(1) and 6(1) of the ICTY and ICTR Statutes}

\section{Planning}

\section{Actus reus}

The notion of planning implies that one or several persons plan or design the commission of a crime within the jurisdiction of the Tribunals at both the preparatory and the execution phases. ${ }^{9}$ The crime planned must be completed in order to trigger the criminal responsibility of the planner. ${ }^{10}$ The level of participation in planning to commit a crime must be substantial, such as actually formulating a plan or endorsing a plan proposed by another individual. ${ }^{11}$ It is sufficient to demonstrate that the planning substantially contributed to the criminal conduct. ${ }^{12}$ The crime, however, need not be executed by the planners, nor is their intervention in the commission of the offence required in any other way. However, in situations which the planner is found to have committed the crime, he or she will not be found responsible for planning the same crime. ${ }^{13}$ In other words, responsibility as the planner of a crime is subsumed within responsibility for the same crime as a perpetrator. ${ }^{14}$ As noted by William Schabas, ' $[t]$ here have been no convictions for the stand-alone crime of planning a crime within the jurisdiction of the [Yugoslavia and Rwanda] tribunals' ${ }^{15}$

\section{Mens rea}

Criminal responsibility for planning requires that the accused directly or indirectly intended that the crime in question be committed. ${ }^{16}$ Thus, if $\mathrm{D}$ planned the ethnic cleansing of a village by force, D could incur criminal responsibility for planning the wilful killings of any of the civilians who are killed during the execution of the plan. In Limaj, the ICTY ruled that '[a] person who plans an act or omission with an intent that a crime will be committed in the execution of that plan, has the requisite mens rea for establishing responsibility under Article 7(1) of the Statute for planning, ${ }^{17}$ The Trial Chamber gave no further clarification with regard to the degree of intent required in order to trigger the criminal responsibility of planning under Article 7(1) of the ICTY Statute. In Nahimana et al. and Dragomir Milošević, the Appeals Chambers of the ICTR and ICTY, respectively, extended the mens rea requisite for this mode of liability to reach the one of dolus eventualis: "the intent to plan the commission of a crime or, at a minimum, the awareness of the substantial likelihood that a crime will be committed in the execution of the acts or omissions planned'. ${ }^{18}$

For an individual to be criminally liable for planning a crime, it is not necessary to prove that any of the persons executing the plan had the requisite mens rea for the offence committed. Suppose high-level political and military leaders, from a distant location, plan the widespread destruction of civilian hospitals and schools in a particular area in order to demoralise the enemy, without the soldiers responsible for carrying out the attacks sharing the objective in question, or even knowing the nature of the relevant targets. In this hypothetical example, the high-level political and military leaders should bear the criminal responsibility for planning, even though none of their troops are criminally liable with respect of execution of the plan.

\section{Instigating}

\section{Actus reus}

According to the Yugoslavia and Rwanda Tribunals, instigating entails prompting another to commit an offence. ${ }^{19}$ Instigation encompasses incitement, but it is much broader than incitement. 
In particular, there is no requirement that instigation be direct and public. ${ }^{20}$ In contrast to ordering as a form of participation under Articles 7(1) and 6(1) of the ICTY and ICTR Statutes, instigation does not necessarily presuppose a hierarchical relationship. ${ }^{21}$ Instigation can be expressed or implied and can also occur by omission rather than by a positive act. ${ }^{22}$ It is not necessary that the original idea or plan to commit the crime be created by the instigator. The Orić Trial Chamber stated,

[e]ven if the principal perpetrator was already pondering on committing a crime, the final determination to do so can still be brought about by persuasion or strong encouragement of the instigator. However, if the principal perpetrator is an 'omnimodo facturus' meaning that he has definitely decided to commit the crime, further encouragement or moral support may merely, though still, qualify as aiding and abetting. ${ }^{23}$

Instigation influence can be generated both face to face and by intermediaries. It can also be excreted over either a small or a large audience provided that the instigator has the corresponding mens rea. ${ }^{24}$ The 'actus reus is satisfied if it is shown that the conduct of the accused [instigator] was a factor substantially contributing to the perpetrator's conduct. ${ }^{25}$ The Gacumbitsi Trial Chamber found that the accused incited the killing of Tutsi in Rusumo commune based on the following evidence: the accused, at various locations, publicly instigated the population to kill the Tutsi; and the accused made speeches at the Rwanteru commercial centre, where shortly after his instigation, those who listened to his speeches participated in looting property belonging to the Tutsi and killing the Tutsi. ${ }^{26}$

One issue is left unresolved under the jurisprudence of the Yugoslavia and Rwanda Tribunals. For situations in which the actus reus of an offence was carried out by several perpetrators, it is questionable whether it must be demonstrated that the instigator have provoked the conduct of all the perpetrators. One might suggest that it is sufficient that the accused instigated the conduct of any one of the perpetrators. A chain of instigation would then be punishable under Articles 7(1) and 6(1) of the ICTY and ICTR Statutes.

\section{Mens rea}

With regard to the mens rea of instigating, the ICTY has consistently held that it is necessary to prove that the instigator either '(a) intended to provoke or induce the commission of the crime [direct intent], or (b) was aware of the substantial likelihood that the commission of a crime would be a probable consequence of his acts' ${ }^{27}$ This runs contrary to the Trial Chamber's ruling in the Kordić case. In this case, the Trial Chamber required proof of the accused's direct intent 'to provoke the commission of the crime'. ${ }^{28}$

\section{Ordering}

Actus reus

The actus reus of ordering 'requires that a person in a position of authority instructs another person to commit an offence'. ${ }^{29}$ There is no requirement that a person giving orders be a sole decision-maker or be the highest or only person in a chain of command. It is possible that a commander who is himself acting on the orders of a hierarchical superior, or who is acting in concert with, or at the command of, other political or military leaders, may nevertheless be criminally responsible for ordering crimes. ${ }^{30} \mathrm{With}$ regard to the existence of a formal superiorsubordinate relationship between the person giving the order and the one executing it, the two ad hoc Tribunals have ruled differently. ${ }^{31}$ 
It is sufficient that the orderer possesses the authority, either de jure or de facto, to order the commission of an offence or that his authority can be reasonably implied. ${ }^{32}$ However, in the absence of such a relationship, the prosecution has to demonstrate that the accused's words of incitement were perceived as orders within the meaning of Articles 7(1) and 6(1) of the ICTY and ICTR Statutes. ${ }^{33}$

There is no requirement regarding the form in which the order must be given $;{ }^{34}$ its existence 'may be proven through direct or circumstantial evidence'. ${ }^{35}$ A causal link between the act of ordering and the physical perpetration of the crime at issue is an ingredient of the actus reus of ordering. ${ }^{36}$ This causal link, however, 'need not be such as to show that the offence would not have been perpetrated in the absence of the order' ${ }^{37}$

\section{Mens rea}

The authoritative judgment concerning the mens rea of ordering was delivered by the ICTY Appeals Chamber in the Blaškić case. ${ }^{38}$ In examining the issue of whether a standard of mens rea lower than direct intent may apply in relation to ordering under Article 7(1) of the Statute, the Appeals Chamber reversed the Trial Chamber's articulations of the mens rea required for ordering:

The knowledge of any kind of risk, however low, does not suffice for the imposition of criminal responsibility for serious violations of international humanitarian law. The Trial Chamber does not specify what degree of risk must be proven. Indeed, it appears that under the Trial Chamber's standard, any military commander who issues an order would be criminally responsible, because there is always a possibility that violations could occur. The Appeals Chamber considers that an awareness of a higher likelihood of risk and a volitional element must be incorporated in the legal standard. ${ }^{39}$

The Appeals Chamber concluded as follows:

A person who orders an act or omission with the awareness of the substantial likelihood that a crime will be committed in the execution of that order, has the requisite men rea for establishing liability under Article 7(1) pursuant to ordering. Ordering with such awareness has to be regarded as accepting that crime. $^{40}$

Giving orders to a particular unit with the awareness of the existence of criminals in its rank amounts to accepting the risk that violent crime may result from their participation in the offensives. ${ }^{41}$ It is unnecessary to establish that those who execute the order possess the same mental state as the one who has issued it. If a commander gives an order to attack a specific position that he knows with certainty is not a military target and civilians are taking refuge there, he could be held criminally liable pursuant to Articles 7(1) and 6(1) of the ICTY and ICTR Statutes for having ordered the wilful killing of civilians, even if those who executed the order lacked the knowledge that they were shelling civilians. In a situation in which none of the subordinates had the relevant mens rea and were merely executing apparently legitimate orders, it may be that the commander could be regarded as having committed wilful killing as an indirect perpetrator (mittelbarer Täter), using his subordinates as instruments. Addressing this point, the Blaškić Trial Judgment ruled that 'what is important is the commander's mens rea, not that of the subordinate executing the order'. ${ }^{42}$ Evidence that a crime has been committed by members of a unit and that its commander was present at the scene 'may be perceived as a significant indicium of his or her encouragement or support', but it does not constitute prima facie evidence of the responsibility of the commander. ${ }^{43}$ 
Participation in crimes in the jurisprudence of the ICTY and ICTR

\section{Aiding and abetting}

\section{Actus reus}

Aiding and abetting is a form of accessorial liability or secondary participation in the commission of a crime. ${ }^{44}$ It applies to situations in which the actus reus of the crime is carried out by a person or persons other than the principal perpetrator. If the offender performes the actus reus of the offence, then the offender is no longer liable as an aider or abettor, but rather as a perpetrator or co-perpetrator of the crime at issue. One might discern that when the accused is responsible for aiding or abetting, and for other forms of liability under Articles 7(1) and 6(1) of the ICTY and ICTR Statutes, the lex specialis principle may lead to the conclusion that ordering or instigating the commission of a crime prevails over responsibility for aiding and abetting.

Although the case law of the ICTY conflates aiding and abetting into a broad, singular legal concept, ${ }^{45}$ ICTR case law views the two terms as distinct legal concepts. ${ }^{46}$ Aiding is the provision of assistance to another in the commission of a crime, whereas abetting is the facilitation of, or the provision of advice in relation to, the commission of an act. ${ }^{47}$ The actus reus for aiding and abetting is that the accused carried out an act that consisted of practical assistance, encouragement or moral support to the principal offender of the crime ${ }^{48}$ The crime that the accused is said to have aided or abetted must actually have been committed. ${ }^{49}$ Mere presence at the scene of the crime without taking action to prevent the occurrence of a crime does not per se constitute aiding and abetting. ${ }^{50}$ However, in cases of an 'approving spectator', or if the presence of a superior can be a significant indicium of encouragement or moral support, mere presence at the scene of a crime that is about to be committed can trigger criminal responsibility for aiding and abetting. ${ }^{51}$

A causal link between the act of assistance and the conduct of the principal offender need not be such as to show that the offence would not have been committed in the absence of such assistance, "but it must have had a substantial effect on the commission of the crime by the principal offender' ${ }^{52}$ The assistance may consist of an act or an omission, and it may occur before, during or after the act of the actual perpetrator. ${ }^{53}$ No prior agreement is required except in $e x$ post facto aiding and abetting. ${ }^{54}$ Ex post facto aiding and abetting requires 'that at the time of the planning, preparation or execution of the crime, a prior agreement exists between the principal and the person who subsequently aids and abets in the commission of the crime'.$^{55}$

\section{Mens rea}

The Orić Trial Chamber noted that while it is undisputed that aiding and abetting requires a subjective element to be proved on the part of the accused, the structure and contents of this mental element are described by the two ad hoc Tribunals in different ways. ${ }^{56}$ Several judgments of the Yugoslavia and Rwanda Tribunals identify intent from the knowledge or awareness of the aider and abettor that his conduct assisted or facilitated the commission of a crime by the principal offender, ${ }^{57}$ whereas other judgments require that the aider or abettor be aware of the essential elements of the crime committed by the principal offender, including the principal offender's state of mind. ${ }^{58}$ Recent judgments demand some sort of volitional element - acceptance of the final result - in addition to the knowledge requirement..$^{59}$ Bearing in mind the evolving law of mens rea in the jurisprudence of the ad hoc Tribunals, the Oric Trial Chamber ruled as follows:

(i) aiding and abetting must be intentional; (ii) the aider and abettor must have 'double intent', namely both with regard to the furthering effect of his own contribution and the intentional completion of the crime by the principal perpetrator; (iii) the intention 
must contain a cognitive element of knowledge and volitional element of acceptance, whereby the aider and abettor may be considered as accepting the criminal result of his conduct if he is aware that in consequence of his contribution, the commission of the crime is more likely than not; and (iv) with regard to the contents of his knowledge, the aider and abettor must at the least be aware of the type and the essential elements of the crime(s) to be committed. ${ }^{60}$

The above Orić test indicates that the mental state of the aider and abettor has to encompass the two components of intent, namely the cognitive and the volitional components. However, the aider and abettor need not share the intent of the principal offender, nor is it necessary that he or she be aware of the specific crime that will be committed by the perpetrator. ${ }^{61}$ If the aider and abettor is aware that one of a number of crimes will probably be committed by the perpetrator, and one of those crimes is in fact committed, then he or she has intended to assist or facilitate the commission of that crime and is guilty as an aider and abettor. ${ }^{62}$

It has been said that the nature of mens rea required for this mode of secondary participation may differ somewhat depending upon whether the participation involves aiding or whether it involves abetting. As stated by William Schabas,

[i]n the case of aiding, the accomplice will often be responsible for a neutral or ambiguous act for example, procuring insecticide, which might be used to exterminate pests in a labour camp, but which might also be used for gas chambers in an extermination camp [as in $Z y k l o n$ B case]. In such cases the Prosecutor will have difficulty convincing judges that the accomplice intended the consequences of his or her acts, because two or more hypotheses may exist. ${ }^{63}$

\section{Committing - direct perpetration}

The jurisprudence of the two ad hoc Tribunals is consistent in holding that committing "covers physically perpetrating a crime or engendering a culpable omission in violation of criminal law' ${ }^{64}$ In this sense, there can be several principal offenders in relation to the same offense when the conduct of each offender satisfies the requisite elements of the substantive offence. ${ }^{65}$ This is the most straightforward form of perpetrating an offence within the subject-matter jurisdiction of the two ad hoc Tribunals, and the plain meaning of the word 'committed' under Articles 7(1) and 6(1), respectively, of the Statutes of these Tribunals.

As will be discussed below, the word 'committed' was defined by the Appeals Chamber of both ad hoc Tribunals to encompass not only those perpetrators who physically perform the criminal conduct but also, in certain circumstances, those who contribute to the crime's commission in execution of a common criminal purpose or joint criminal enterprise. ${ }^{66}$

\section{Actus reus}

With regard to the actus reus required for committing, it must be established that 'the accused participated, physically or otherwise directly, in the material elements of a crime provided for in the Statute[s], through positive acts or omissions'. ${ }^{67}$

\section{Mens rea}

The mens rea for committing under Articles 7(1) and 6(1) of the ICTY and ICTR Statutes differs from the one required for other modes of participation (for example, instigating and aiding and 
abetting) in that the accused who physically performs the material elements of the offence must possess the full mens rea required for the crime, including any specific intent or grounds required by its definition. Thus, to incur criminal responsibility for committing a specific intent crime (for example, terror against the civilian population), 'the Prosecution is required to prove not only that the Accused accepted the likelihood that terror would result from the illegal acts - or, in other words, that he was aware of the possibility that terror would result - but that that was the result which he specifically intended' ${ }^{68}$ Thus, knowledge, dolus eventualis or advertent recklessness are not sufficient mental states to hold an accused criminally liable for committing specific intent crimes, although these mental states may be sufficient to trigger criminal responsibility for the same type of offences with respect to other modes of participation under Articles 7(1) and $6(1)$ of the ICTY and ICTR Statutes.

\section{Committing through participation in a joint criminal enterprise}

Although the Statutes of the two ad hoc Tribunals do not make explicit reference to the notion of joint criminal enterprise (JCE), the Appeals Chambers of these Tribunals have held that participating in a JCE is a form of liability that exists in customary international law and is a form of commission under Articles 7(1) and 6(1) of the Statutes. ${ }^{69}$ Discussing the concept of joint criminal enterprise, the Tadić Appeals Chamber stressed the importance of expanding the concept of primary participation, as opposed to secondary participation, beyond those who physically carry out the criminal conduct:

Although only some members of the group may physically perpetrate the criminal act ... the participation and contribution of the other members of the group is often vital in facilitating the commission of the offence in question. It follows that the moral gravity of such participation is often no less - or indeed different - from that of those who actually carry out the acts in question. ${ }^{70}$

Evidentially, JCE as a mode of criminal liability has become the prosecution's 'darling notion', ${ }^{71}$ though legal commentators doubt its validity. ${ }^{72}$

\section{General requirements for joint criminal enterprise liability}

It is settled in the jurisprudence of the two ad hoc Tribunals that the word 'committed', as provided for in Articles 7(1) and 6(1) of the ICTY and ICTR Statutes, includes three forms of joint criminal enterprise: namely, the basic, the systemic, and the extended forms. ${ }^{73}$ The required actus reus for each of these forms comprises three elements: (1) a plurality of persons; (2) the existence of a common purpose that amounts to or involves the commission of a crime provided for in the Statutes; ${ }^{74}$ and (3) the participation of the accused in the common purpose.

This mode of liability need not involve the physical commission of a specific crime by all the members of JCE but may take the form of assistance in, or contribution to, the execution of the common purpose. ${ }^{75}$ Thus, 'once a participant in a joint criminal enterprise shares the intent of that enterprise, his participation may take the form of assistance or contribution with a view to carry out the common plan or purpose' ${ }^{76}$ While a Trial Chamber must identify the plurality of persons belonging to the JCE, it is not necessary to identify each of the persons involved by name. Rather, it is sufficient to refer to categories or groups of persons. ${ }^{77}$ The ${ }^{6}$ common objective need not have been previously arranged or formulated, and .... it may materialise 
extemporaneously and be inferred from the fact that a plurality of persons acts in unison to put into effect a joint criminal enterprise'. ${ }^{78}$ The same applies to the expansions of criminal means. ${ }^{79}$ A Trial Chamber need not to decide whether there was 'a consensus or shared understanding amounting to a psychological causal nexus' between the accused and other members of the JCE. ${ }^{80}$

\section{The basic form of JCE (JCE I)}

The first form of JCE arises when all co-perpetrators, acting pursuant to a common purpose, possess the same criminal intent. ${ }^{81}$ An example is a plan formulated by the co-defendants in the JCE to commit the act of murder; although each of the co-defendan ts may carry out a different role, they all have the intent to murder. ${ }^{82}$ This basic form of JCE encompasses two different types of participation in a crime within the ratione materiae jurisdiction of the two ad hoc Tribunals. The first scenario, direct perpetration, appears when the conduct of each of the co-defendants satisfies the actus reus of the crime at issue. The second scenario appears when a participant in a JCE does not carry out, or cannot be proven to have carried out, the actus reus at issue. In this situation, the following objective and subjective prerequisites have to be established in order to hold the accused criminally responsible as a co-perpetrator in the JCE:

(i) the accused must voluntarily participate in one aspect of the common design (for instance, by inflicting non-fatal violence upon the victim, or by providing material assistance to or facilitating the activities of his co-perpetrators; (ii) the accused, even if not personally effecting the killing, must nevertheless intend this result. ${ }^{83}$

It has been argued whether a member of the JCE can incur criminal responsibility for the acts of persons who were not members of the JCE and who potentially did not even know of the existence or purpose of the JCE. ${ }^{84}$ Recent case law of the ICTY has answered this in the affirmative, provided that it has been established that the crimes can be imputed to at least one member of the JCE and that this member - when using the principal perpetrators - acted in accordance with the common objective'. ${ }^{85}$

The argument that a co-perpetrator in a JCE must physically commit part of the actus reus of a crime in order to be criminally liable was rejected by the Kvocka Appeals Chamber, which stated that, on the grounds that 'a participant in a joint criminal enterprise need not physically participate in any element of any crime, so long as the requirements of joint criminal enterprise responsibility are met'. ${ }^{86}$

\section{Mens rea}

The mens rea required for the basic form of JCE is the intent to take part in a criminal enterprise and to further - individually and jointly - the criminal purpose of that enterprise. It must be established that the accused voluntarily participated in one aspect of the common design while being aware of the criminal character of the enterprise. The accused need not have knowledge of every criminal incident committed in furtherance of the enterprise. In the words of Tadic Appeals Chamber, 'what is required is the intent to perpetrate a certain crime (this being the shared intent on the part of all co-perpetrators). ${ }^{87}$

In this category of JCE, all co-perpetrators must possess the mens rea required for the crime at issue. For instance, when the crime committed is extermination, it must be established that all the co-perpetrators, even those not physically perpetrating the killing, had the conscious 
objective of killing persons on a massive scale, inflicting serious bodily injury or creating conditions of life that lead to the death of a large number of persons. In the alternative, it must be shown that the co-perpetrators proceeded in the knowledge that mass extermination would be the probable outcome and reconciled themselves to this and made peace with this fact.

\section{The systemic form of JCE (JCE II)}

The systemic form of JCE is based on the post-World War II concentration camp cases, in which the notion of common purpose was applied to situations in which the offences charged were alleged to have been committed by members of military or administrative units, such as those running concentration camps - groups acting pursuant to a concerted plan. ${ }^{88}$ This mode of liability can be attached to those responsible for carrying out a task within a criminal design that is implemented in an institutional framework, such as an internment or concentration camp. ${ }^{89}$

\section{Actus reus}

The actus reus of the systemic form of JCE entails the same objective elements as the first category. The participation in this form of JCE need not involve the commission of a particular crime within the subject-matter jurisdiction of the Tribunals but may take the form of assistance in, or contribution to, the execution of the common purpose. ${ }^{90}$

Given the fact that the general rule governing JCE liability does not require proof of substantial contribution to the enterprise, ${ }^{91}$ it was argued that 'opportunistic visitors' who enter a camp occasionally and mistreat its detainees could be held responsible as participants in the enterprise. ${ }^{92}$ Addressing this point, the Kvock $k$ Appeals Chamber asserted that in the case of 'opportunistic visitors', a substantial contribution to the overall effect of the Omarska detention camp would be necessary to establish responsibility under the JCE doctrine. ${ }^{93}$

\section{Mens rea}

There is consensus within the jurisprudence of the ICTY that the mental state required for the systemic form of JCE is the participant's personal knowledge of the nature of the system in question and the intent to further the concerted system of ill treatment. ${ }^{94}$ Similar to the basic form, the participants in the systemic form of JCE must be shown to share the required intent of the principal perpetrators. ${ }^{95}$ The Krnojelac Appeals Chamber distinguished between three different scenarios with respect to crimes committed in the 'KP Dom': (1) crimes within the system's common purpose, (2) crimes beyond the system's common purpose; and (3) crimes that implicated several co-perpetrators but could not be recognized as constituting a purpose common to all the participants in the system. ${ }^{96}$

As for the mens rea required by a participant in a system in which a 'common denominator' exists among all the participants in that system, it is sufficient to prove that the accused participating in the system was aware that particular crimes were being committed by another participant and that the accused intended to further the system in place. ${ }^{97}$ The Krnojelac Appeals Chamber held that in such scenarios, all the participants in the system should be considered as coming under a first-category JCE without reference to the concept of system. ${ }^{98}$

\section{The extended form of JCE (JCE III)}

The third form of joint criminal enterprise concerns those participants who share a common purpose - for instance, to forcibly transfer civilians from an occupied territory - but do not share 
the intent to commit a criminal act that falls beyond the common purpose - for instance, murdering one or more members of the transferred group. Under this category of JCE, participants who did not intend to commit murder would still be held criminally responsible upon proof that they were nevertheless in a position to foresee the commission of murder and willingly took the risk. According to the Stakić Appeals Judgment, for the application of third-category JCE liability, the following elements must be satisfied:

(a) crimes outside the Common Purpose have occurred;

(b) these crimes were a natural and foreseeable consequence of effecting the Common Purpose; and (c) the participant in the joint criminal enterprise was aware that the crimes were a possible consequence of the execution of the Common Purpose, and in that awareness, he nevertheless acted in furtherance of the Common Purpose. ${ }^{99}$

The distinctive feature of the extended form of JCE is the 'fault element', which, subject to certain conditions, permits criminal liability to be extended to crimes other than those initially agreed upon in the plan or design. This third category of JCE requires not only that an individual, by his or her controlled acts, has taken unlawful risks in violation of international humanitarian law but also that he or she has assumed the risk of criminal results arising from the common criminal design, regardless of who commits those crimes.

One serious problem that confronted the two ad hoc Tribunals is the applicability of the extended form of JCE to specific intent crimes: notably, genocide. It is questionable whether individuals should be convicted of such high-profile and morally culpable crimes on the basis of mere foresight. Addressing this point, the Stakic Trial Chamber spelled out its concerns in the following words:

[T] he application of a mode of liability can not replace a core element of a crime. The Prosecution confuses modes of liability and the crimes themselves. Conflating the third variant of joint criminal enterprise and the crime of genocide would result in the dolus specialis being so watered down that it is extinguished. ${ }^{100}$

In addition, those crimes that require specific intent are generally regarded as the most serious, and an attempt to undermine the mental element - charging individuals for specific intent crimes under the extended form of JCE - devalues the seriousness of these crimes. These concerns were spelled out by the Bardanin Trial Chamber. It held that the specific intent required for a conviction of genocide cannot be reconciled with the mens rea standard for an extended form of joint criminal enterprise. ${ }^{101}$ The Trial Chamber concluded that the accused's awareness of the risk that genocide would be committed by other members of the joint criminal enterprise was incompatible with and fell short of the threshold needed to satisfy the specific intent required for a genocide conviction. ${ }^{102}$ Notably, the Bardanin Trial Chamber's finding was reversed by the Appeals Chamber Decision on Interlocutory Appeal. ${ }^{103}$

A major source of concern with regard to the applicability of the extended form of JCE in the sphere of international criminal law is that under both the objective and subjective standards, the participant is unfairly held liable for criminal conduct that they did not intend and in which they did not participate. It is also unjust that the liability of the actual perpetrator, who carried out the crime outside the common plan, is tested subjectively, whereas the liability of the participant is tested objectively. Moreover, if the accused had actually participated in crimes outside the initial 'common purpose' as an aider or abettor, he or she would arguably have an increased chance of acquittal, as the Prosecution would be confronted with having to prove a higher level of mental awareness: namely, 
that the accused knew that the principal perpetrator had the state of mind required for the crime at issue. ${ }^{104}$ This author is of the opinion that if, one day, the Prosecution succeeds in securing a conviction for one of the 'specific purpose crimes' under the third category of joint criminal enterprise, this will alter the JCE doctrine to become a device used to 'just convict everyone'. ${ }^{105}$

\section{Co-perpetration as a form of 'committing'}

In examining the criminal responsibility of Dr. Milomir Stakić for the crimes alleged, a Trial Chamber of the ICTY applied a mode of liability that it termed 'co-perpetratorship', committing 'jointly with another person, in lieu of JCE. ${ }^{106}$ In the words of the Stakic Trial Chamber, the main features of co-perpetration are that the "co-perpetrators must pursue a common goal, either through an explicit agreement or silent consent, which they can only achieve by coordinated action and joint control over the criminal conduct. Each co-perpetrator must make a contribution essential to the commission of the crime'. ${ }^{107}$ In order to meet the requirements of co-perpetratorship as a mode of liability, the Prosecution must prove beyond reasonable doubt that there was an explicit agreement or silent consent between two or more individuals to reach a common goal by coordinated cooperation with joint control over the criminal conduct. ${ }^{108}$ Under the Stakic Judgment, this form of liability will occur when co-perpetrators can only realize their plan insofar as they act jointly, but each individual can ruin the whole plan if he does not carry out his part. To this extent, each of the co-perpetrators is considered to be in control of the criminal act. ${ }^{109}$

In addition to the mens rea required for the particular crime, this mode of liability, coperpetratorship, requires proof of (1) mutual awareness of substantial likelihood that crimes would occur and (2) the defendant's awareness of the importance of his or her own role. ${ }^{110}$

Despite the fact that the Stakic Trial Judgment limited itself to the clear wording of the Statute when interpreting 'committing' in the form of 'co-perpetration' in lieu of JCE, the Stakic Appeals Chamber's recent judgment marked the death of this mode of liability in the jurisprudence of the ICTY. ${ }^{111}$

\section{Responsibility under Articles 7(3) and 6(3) of the ICTY and ICTR statutes}

The principle of individual criminal responsibility of commanders for failure to prevent or punish crimes committed by their subordinates is not alien to international criminal law. It is a well-established rule of customary international law applicable to both international and internal armed conflicts. ${ }^{112}$ Articles 7(3) and 6(3) of the ICTY and ICTR Statutes, in contrast to Articles $7(1)$ and 6(1), create a form of indirect liability 'predicated upon the power of the superior to control the acts of his subordinates'. ${ }^{113}$ A recent judgment expressly stated that command responsibility as provided for in Article 7(3) of the ICTY Statute is responsibility for an omission. ${ }^{114}$

\section{General requirements under Articles 7(3) and 6(3) of the ICTY and ICTR statutes}

For a superior, military or civilian, ${ }^{115}$ to be found criminally responsible under Articles 7(3) and $6(3)$ of the Statutes, the following elements have to be established beyond reasonable doubt:

(i) an act or omission incurring criminal responsibility within the subject matter jurisdiction of the Tribunals has been committed by other(s) than the accused ('principal crime'); (ii) there existed a superior-subordinate-relationship between the accused and the principal perpetrator(s) ('superior-subordinate-relationship'); (iii) the accused as a superior knew or 
had reason to know that the subordinate was about to commit such crimes or had done so ('knew or had reason to know'); and (iv) the accused as a superior failed to take the necessary and reasonable measures to prevent such crimes or punish the perpetrator(s) thereof ('failure to prevent or punish'). ${ }^{116}$

\section{A crime was committed}

The first element requires that a perpetrator or group of perpetrators other than the accused has committed a crime within the subject-matter jurisdiction of the two ad hoc Tribunals. It has been argued that because Article 7(3) of the ICTY Statute merely refers to committing and does not expressly mention the other modes of liability set out in Article 7(1) of the Statute, a superior can incur criminal responsibility only if his subordinates committed the crimes themselves and not if they merely aided and abetted the crimes of others. ${ }^{117}$ Addressing this point, the Oric Judgment, as well as the Boškoski Decision, ruled that superior responsibility is not limited to crimes committed physically by the subordinates as principal perpetrators, as this form of liability also encompasses situations in which the subordinates merely aided and abetted the crimes of others as accessories or secondary participants. ${ }^{118}$

A superior's criminal responsibility is not limited to situations of a subordinate's active perpetration or participation, but also comprises the commission of crime by omission. ${ }^{119}$ The following hypothetical example given by the Oric' Trial Chamber is illustrative:

if for instance the maltreatment of prisoners by guards, and/or by outsiders not prevented from entering the location, is made possible because subordinates in charge of the prison fail to ensure the security of the detainees by adequate measures, it does not matter any further by whom else, due to the subordinates' neglect of protection, the protected persons are being injured, nor would it be necessary to establish the identity of the direct perpetrators. ${ }^{120}$

The ICTY emphasized that in any mode of criminal participation, 'omission can incur responsibility only if there was a duty to act in terms of preventing the prohibited result from occurring. ${ }^{121}$

\section{Superior authority over the subordinates}

The requirement of a superior-subordinate relationship, which 'lies in the very heart of a commander's liability for crimes committed by his subordinates', ${ }^{122}$ is best encapsulated by the Ntagerura Trial Chamber:

(i) a superior-subordinate relationship is established by showing a formal or informal hierarchical relationship; (ii) the superior must have possessed the power or the authority, de jure or de facto, to prevent or punish an offence committed by his subordinates; (iii) the superior must have had effective control over the subordinates at the time the offence was committed. ${ }^{123}$

\section{Effective control - material ability}

The concept of effective control, which is the decisive criterion for establishing the superiorsubordinate link, is defined by the Čelebicíi Appeals Chamber as connoting the commander's material ability to prevent and punish criminal conduct. ${ }^{124}$ Effective control is more a matter of evidence than of law, and 'those indicators [of effective control] are limited to showing that the 
accused had the power to prevent, punish or initiate measures leading to proceedings against the alleged perpetrators where appropriate. ${ }^{125}$ Thus, the effective control requirement is not satisfied by a showing of mere general influence on the part of the accused. ${ }^{126}$

\section{De jure and/or de facto}

The jurisprudence of the ICTY and the ICTR confirms that formal designation as a commander or a superior is not a prerequisite for superior responsibility and that such responsibility may be imposed by virtue of a person's de facto, as well as de jure, position of authority or powers of control. ${ }^{127}$ In the words of the Orić Trial Chamber, 'regardless of which chain of command or position of authority the superior-subordinate relationship may be based on it is immaterial whether the subordination of the perpetrator to the accused as superior is direct or indirect, and formal or factual'. ${ }^{128}$

\section{Mens rea - 'knew or had reason to know'}

It has been repeatedly cautioned, at least as it is understood and applied within the framework of the Yugoslavia and the Rwanda Tribunals, that command responsibility is not a mode of strict liability. ${ }^{129} \mathrm{~A}$ commander, whether military or civilian, will be found to possess the requisite mens rea sufficient to hold him responsible under Articles 7(3) and 6(3) of the ICTY and ICTR Statutes when the commander knew (actual knowledge) or had reason to know (imputed or constructive knowledge) that the subordinate was about to commit or had committed a crime. ${ }^{130}$ It must be established either that the commander had actual knowledge that his or her subordinates were committing or about to commit crimes within the subject-matter jurisdictions of the Tribunals or that the commander had in his or her possession information that would at least put him or her on notice of the risk of such offences. ${ }^{131}$ With regard to the latter form (imputed knowledge), one Trial Chamber of the Yugoslavia Tribunal noted that

by permitting the attribution of criminal responsibility to a superior for what is in actual fact a lack of due diligence in supervising the conduct of his subordinates, Article 7(3) in this respect sets itself apart being satisfied with a mens rea falling short of the threshold requirement of intent under Article 7(1) of the Statute. ${ }^{132}$

\section{Mens rea - actual knowledge}

As a mode of liability, command responsibility requires the Prosecution to establish that a commander, whether military or civilian, 'knew' of the criminality of subordinates. Thus, this mode of liability does not require proof of intent in its strict sense on the part of the superior before criminal liability can attach. ${ }^{133}$ The term 'knew', as provided for in Articles 7(3) and 6(3) of the Statutes, implies actual knowledge - the superior's awareness that the relevant crimes were committed or were about to be committed. ${ }^{134}$ This is the highest standard of knowledge and the hardest to prove, as it requires evidence establishing beyond reasonable doubt that the commander actually knew of the crimes committed or about to be committed by his subordinates. ${ }^{135}$ It is not required, on the one hand, to prove that the commander possesses any volitional element with regard to the crimes committed by his subordinates. On the other hand, under this formulation of 'actual knowledge', recklessness or negligence is not a sufficient fault element to trigger the criminal responsibility of a commander for the proscribed acts committed by his or her subordinates. ${ }^{136}$ 
It is worth stressing that in situations in which there is sufficient evidence to establish that superiors, in addition to possessing knowledge that crimes were committed or were about to be committed by their subordinates, have substantially contributed to the commission of these crimes, this may transform their responsibility to 'complicity' under Articles 7(1) and 6(1) of the ICTY and ICTR Statutes. As one Trial Chamber of the Yugoslavia Tribunal noted,

[i]n cases where the evidence presented demonstrates that a superior would not only have been informed of subordinates' crimes committed under his authority, but also exercised his powers to plan, instigate or otherwise aid and abet in the planning, preparation or execution of these crimes, the type of criminal responsibility incurred may be better characterised by Article 7(1). Where the omissions of an accused in a position of superior authority contribute (for instance by encouraging the perpetrator) to the commission of a crime by a subordinate, the conduct of the superior may constitute a basis for liability under Article $7(1) \cdot{ }^{137}$

The Čelebići Trial Chamber rightly emphasised that in the absence of direct evidence of the superior's knowledge of the offences committed by his subordinates, such knowledge cannot be presumed, but must be established by way of circumstantial evidence'. ${ }^{138}$ Types of circumstantial evidence include

the number, type and scope of illegal acts, time during which illegal acts occurred, number and types of troops and logistics involved, geographical location, whether the occurrence of the acts is widespread, tactical tempo of operations, modus operandi of similar illegal acts, officers and staff involved, and location of the commander at the time. ${ }^{139}$

\section{Imputed knowledge - had reason to know}

The standard of 'had reason to know', which constitutes the alternative type of knowledge as set out in Articles 7(3) and 6(3) of the ICTY and ICTR Statutes, is based on Articles 86 and 87 of Additional Protocol I to the 1949 Geneva Conventions. The 'had reason know' standard does not require proof of 'actual knowledge' on the part of the superior. ${ }^{140}$ Thus, if the superior is in possession of sufficient information to put him or her on notice of the likelihood of illegal acts by his or her subordinates - if the information available is sufficient to justify further inquiry - he or she may be regarded as 'having reason to know'. ${ }^{141}$

Mere expectation that offences were about to be committed is not sufficient to imply that the superior 'had reason to know'. ${ }^{142}$ According to the Blaskić Appeals Chamber, a superior can incur responsibility 'for deliberately refraining from finding out but not for negligently failing to find out.' ${ }^{143}$

Superiors' knowledge of the criminal reputation of their subordinates may be sufficient to meet the 'had reason to know' standard if it amounts to information that would put them on notice of the present and real risk of offences within the jurisdiction of the Tribunals. ${ }^{144}$ The findings of the Israeli Commission of Inquiry responsible for investigating the massacre perpetrated in the Sabra and Shatilla refugee camps in Beirut in 1982 is illustrative. ${ }^{145}$ In examining the responsibility of the Chief of Staff of the Israel Defence Forces, the Commission held that 'his knowledge of the feelings of hatred of the particular forces involved towards the Palestinians did not justify the conclusion that the entry of those forces into the camps posed no danger. ${ }^{146}$ The Commission went on to hold as follows: 
[t]he absence of a warning from experts cannot serve as an explanation for ignoring the danger of a massacre. The Chief of Staff should have known and foreseen - by virtue of common knowledge, as well as the special information at his disposal - that there was a possibility of harm to the population in the camps at the hands of the Phalangists. Even if the experts did not fulfil their obligation, this does not absolve the Chief of Staff of Responsibility. ${ }^{147}$

It should be noted that a superior cannot be found responsible for failing to acquire information in the first place. ${ }^{148}$ In the words of the Celebici $i$ Appeals Chamber

[n] eglect of a duty to acquire such knowledge, however, does not feature in the provision [Article 7(3)] as a separate offence, and a superior is not therefore liable under the provision for such failures but only for failing to take necessary and reasonable measures to prevent or to punish. ${ }^{149}$

However, in situations in which the superior had the means to obtain the relevant information of a crime and deliberately refrained from doing so, he or she may be held responsible under the doctrine of command responsibility. ${ }^{150}$

Some Trial Chambers of the Yugoslavia and Rwanda Tribunals considered criminal negligence to be a sufficient fault element to hold a superior criminally responsible for crimes committed by his or her subordinates. ${ }^{151}$ The Appeals Chamber, however, overturned these findings, assuring that 'criminal negligence' is not a basis of liability in the context of command responsibility ${ }^{152}$ and that such references to negligence are 'likely to lead to confusion of thought'. ${ }^{153}$ The Appeals Chamber, while rejecting criminal negligence as a sufficient fault element for superior responsibility, failed to identify which degree of knowledge is sufficient in cases in which the superior 'had reason to know'. Recent judgments rendered by the ICTY provide further clarification as to the nature of the definition of 'had reason to know':

By contenting itself with having had 'reason to know' instead of requiring actual knowledge, superior criminal responsibility under Article 7(3) of the Statute obviously does not presuppose intent of the superior with regard to crimes of his subordinates, let alone a malicious one. What is required though, beyond solely negligent ignorance, is the superior's factual awareness of information which, due to his position, should have provided a reason to avail himself or herself of further knowledge. Without any such subjective requirement, the alternative basis of superior criminal responsibility by having had 'reason to know' would be diminished into a purely objective one and, thus, run the risk of transgressing the borderline to 'strict liability'. This is not the case, however, as soon as he or she has been put on notice by available information as described above. ${ }^{154}$

\section{Failure to prevent or punish}

To establish criminal responsibility under Articles 7(3) and 6(3) of the ICTY and ICTR Statutes, the Prosecution must demonstrate, in addition to the superior's actual or imputed knowledge of crimes that are about to be committed or have been committed by his or her subordinates, that he or she failed to take necessary and reasonable measures to prevent such acts or to punish the perpetrator thereof.Thus, as already stated by the ICTY Appeals Chamber, the neglect of a duty to acquire such knowledge does not feature within Article 7(3) of the Statute as a separate offence. Rather, it is merely an element within the superior criminal responsibility for failure to prevent or punish. 
The superior's obligations to prevent and punish are consecutive and do not provide the accused with two alternative and equally satisfactory options. ${ }^{155}$ Thus, 'where the accused knew or had reason to know that subordinates were about to commit crimes and failed to prevent them, he cannot make up for the failure to act by punishing the subordinates afterwards'. ${ }^{156}$ Professor William Schabas once noted that 'the superior is being punished for failure to supervise rather than for the offence itself' ${ }^{157}$ He continued, 'to the extent that the superior can demonstrate that he or she actually fulfilled the duty to prevent such crimes, we are indeed in the presence of a strict liability offence, as this concept is generally understood in criminal law'. ${ }^{158}$

\section{General remarks and observations}

The systematic analysis of the jurisprudence of the Yugoslavia and Rwanda Tribunals reveals that the case law of these Tribunals does not state a consistent mens rea for accomplice liability. Sometimes the Tribunals require a dolus directus of the first degree on the part of the accomplice to bring about the crime; sometimes dolus directus of the second degree; sometimes knowledge; and sometimes they use a language that embraces recklessness. ${ }^{159}$

Recent judgments delivered by the Appeals and Trial Chambers have required proof of some sort of volitional element on the part of the accused in addition to the cognitive element of knowledge. ${ }^{160}$ They also ruled out recklessness and gross negligence from being sufficient fault elements for accessorial liability. On this particular point, one might recall the Commentaries of the Model Penal Code:

The culpability required to be shown of the principal actor, is normally higher than negligence .... To say that the accomplice is liable if the offence committed is 'reasonably foreseeable' or the 'probable consequence' of another crime is to make him liable for negligence, even though more is required in order to convict the principal actor. This is both incongruous and unjust; if anything, the culpability level for the accomplice should be higher than that of the principal actor, because there is generally more ambiguity in the overt conduct engaged in by the accomplice, and thus a higher risk of convicting the innocent. ${ }^{161}$

In light of these developments it is submitted that accomplice liability requires the existence of a mental element on the part of the accused. That is to say both a cognitive element of knowledge (awareness or contemplation) and a volitional element (acceptance of the result) must be incorporated into the legal standards. ${ }^{162}$

As for the third category of JCE, it is submitted that the 'reasonable foreseeable' test applied by the two ad hoc Tribunals is unfair. On that particular point, one might recall the strong dissenting judgment delivered by Justice Michael Kirby in the High Court of Australia in a murder case:

To hold an accused liable for murder merely on the foresight of a possibility is fundamentally unjust. It may not be truly a fictitious or 'constructive liability'. But it countenances what is 'undoubtedly a lesser form of mens rea'. It is a form that is an exception to the normal requirements of criminal liability. And it introduces a serious disharmony in the law, particularly as that law affects the liability of secondary offenders to conviction for murder upon this basis. ${ }^{163}$

Thus, this author recommends the reform of the 'reasonably foreseeable' standard of the extended form of joint criminal enterprise through the adoption of a dolus eventualis standard, 
requiring that the accused have foreseen the commission of the crime that went beyond the common plan as not merely a possibility, but rather as a high probability, and that he or she accepted its occurrence and made peace with it.

\section{Notes}

1 Statute of the International Criminal Tribunal for the former Yugoslavia, UN Doc. S/RES/827 (1993).

2 Statute of the International Criminal Tribunal for Rwanda, UN Doc. S/RES/955 (1994).

3 See ICTY Statute, Art. 6; ICTR Statute Art. 5.

4 Report of the Secretary-General pursuant to para. 2 of the Security Council Resolution 808 (1993), S/25704, 3 May 1993, paras 50-51. Some legal scholars hold the opinion that corporate entities should be held criminally liable for violations of international criminal law. See, for instance, R.C. Slye, 'Corporations, Veils, and International Criminal Liability', Brookline Journal of International Law 33, 2008 , 955-73; K. Magraw, 'Universally Liable? Corporate-Complicity Liability under the Principle of Universal Jurisdiction', Minnesota Journal of International Law 18, 2009, 458-97; J. Kyriakakis, 'Corporations and the International Criminal Court: The Complementarity Objection Stripped Bare', Criminal Law Forum 19, 2008 115-151; W. Schabas, 'Enforcing International Humanitarian Law: Catching the Accomplices', International Review of the Red Cross 83, 2001, 439-58; A. Clapham, 'The Question of Jurisdiction Under International Criminal Law Over Legal Persons: Lessons from the Rome Conference on an International Criminal Court', in M.T. Kamminga and S. Zia-Zarifi (eds), Liability of Multinational Corporations Under International Law, Hague, Kluwer, 2000, pp. 139-95; A. Clapham, 'Extending International Criminal Law beyond the Individual to Corporations and Armed Opposition Groups', Journal of International Criminal Justice 6, 2008, 899-926.

5 See ICTY Statute Art. 7(1)(3); ICTR Statute Art. 6(1)(3).

6 Tadić (IT-94-1-A), Appeals Chamber, 15 July 1999, para. 186; Kordić \& Čerkez (IT-95-14/2-T), 26 February 2001, para. 364.

7 Tadić (IT-94-1-A) Appeals Chamber, 15 July 1999, paras. 220, 227-228; Furundžija (IT-95-17/1-T), 10 December 1998, para. 216; Kordić \& Čerkez (IT-95-14/2-T), 26 February 2001, para. 364.

8 Tadić (IT-94-1-A), Appeals Chamber, 15 July 1999, para 188; Delalić et al. (Čelebići Case) (IT-9621-A), Appeals Chamber, 20 February 2001, paras 215-268; Kordić \& Čerkez (IT-95-14/2-T), 26 February 2001, para. 364; Aleksovski (IT-95-14/1-T), 25 June 1999, paras. 69-81. See also Report of the Secretary-General pursuant to para. 2 of the Security Council Resolution 808 (1993), S/25704, 3 May 1993 (Secretary-General Report) paras 53-58.

9 Gacumbitsi (ICTR-2001-64-T), 17 June 2004, para. 271, citing Blaškić (IT-95-14-T), 3 March 2000, para. 386; Musema (ICTR-96-13-T), 27 January 2000, para. 119;Akayesu (ICTR-96-4-T), 2 September 1998, para. 480; Kajelijeli (ICTR-98-44A-T), 1 December 2003, para. 761; Kamuhanda (ICTR-9554A-T), 22 January 2004, para. 592. For the ICTY, see Limaj (IT-03-66), 30 November 2005, para. 513; Brđanin (IT-99-36-T), 1 September 2004, para. 268; Krstić (IT-98-33-T), 2 August 2001, para. 601; Stakić (IT-97-24-T), 31 July 2003, para. 443. Milošević (IT-98-29/1-A), Appeals Chamber, 12 November 2009, para. 268; Kordić and Čerkez (IT-95-14/2-A), Appeals Chamber, 17 December 2004, para. 26.

10 Akayesu (ICTR-96-4), 2 September 1998, para. 473; Limaj (IT-03-66), 30 November 2005, para. 513; Kordić and Čerkez (IT-95-14/2-A),Appeals Chamber, 17 December 2004, para. 26. But see G. Mettraux, International Crimes and the ad hoc Tribunals, Oxford: Oxford University Press, 2005, 279-80. For different opinion see W. Schabas, The UN International Criminal Tribunals: The former Yugoslavia, Rwanda and Sierra Leone, Cambridge: Cambridge University Press, 2006, p. 299.

11 Bagilishema (ICTR-95-1A-T), 7 June 2001, para. 30.

12 Milošević (IT-98-29/1-A), Appeals Chamber, 12 November 2009, para. 268.

13 Galić (IT-98-29-S), 30 March 2004, fn. 280.

14 Ibid.

15 Schabas, The UN International Criminal Tribunals, p. 299.

16 Blaškić (IT-95-14-T), 3 March 2000, para. 278; Kordić \& Čerkez (IT-95-14/2-T), 26 February 2001, para. 386.

17 Limaj (IT-03-66), 30 November 2005, para. 513, citing with approval Kordić and Čerkez (IT-9514/2-A), Appeals Chamber, 17 December 2004, para. 31.

18 Dragomir Milošević (IT-98-29/1-A), Appeals Judgment, 12 November 2009, para. 268. 


\section{Mohamed Elewa Badar}

19 Limaj (IT-03-66), 30 November 2005, para. 514; Brđanin (IT-99-36-T), 1 September 2004, para. 269; Kamuhanda (ICTR-95-54A-T), 22 January 2004, para. 593; Akayesu (ICTR-96-4), 2 September 1998, para. 482; Blaškić (IT-95-14-T), 3 March 2000, para. 280; Krstić (IT-98-33-T), 2 August 2001, para. 601; Kordić (IT-95-14/2-T), 26 February 2001, para. 387; Gacumbitsi (ICTR-2001-64-T), 17 June 2004, para. 279; Kajelijeli (ICTR-98-44A-T), 1 December 2003, para. 762; Bagilishema (ICTR-95-1A-T), 7 June 2001, para. 30 .

20 Gacumbitsi (ICTR-2001-64-T), 17 June 2004, para. 279, citing Semanza (ICTR-97-20-T), 15 May 2003, para 381; Bagilishema (ICTR-95-1A-T), 7 June 2001, para. 30; Akayesu (ICTR-96-4), Appeals Chamber, 1 June 2001, paras. 478-482; Kajelijeli (ICTR-98-44A-T), 1 December 2003, para. 762.

21 A. Cassese, International Criminal Law, Oxford: Oxford University Press, 2003, p. 189.

22 Limaj (IT-03-66), 30 November 2005, para. 514; Brđanin (IT-99-36-T), 1 September 2004, para. 269, citing Blaškić (IT-95-14-T), 3 March 2000, para. 280; Kajelijeli (ICTR-98-44A-T), 1 December 2003, para. 762; Kamuhanda (ICTR-95-54A-T), 22 January 2004, para. 593.

23 Orić (IT-03-68-T), 30 June 2006, para. 271 (footnotes omitted).

24 Orić (IT-03-68-T), 30 June 2006, para. 273 (emphasis added, footnotes omitted).

25 Kordić and Čerkez (IT-95-14/2-A), Appeals Chamber, 17 December 2004, para. 27. See also Brđanin (IT-99-36-T), 1 September 2004, para. 269.

26 Gacumbitsi (ICTR-2001-64-T), 17 June 2004, para. 279

27 Kordić and Čerkez (IT-95-14/2-A), Appeals Chamber, 17 December 2004, para. 32; Limaj (IT-03-66), 30 November 2005, para. 514; Brđanin (IT-99-36-T), 1 September 2004, para. 269 (emphasis added).

28 Kordić and Čerkez (IT-95-14/2-T), 26 February 2001, para. 387.

29 Limaj (IT-03-66), 30 November 2005, para. 515, citing Kordić and Čerkez (IT-95-14/2-A), Appeals Chamber, 17 December 2004, para. 28; Strugar (IT-01-42-T), 31 January 2005, para. 331. Krstić (IT-9833-T), 2 August 2001, para. 601.

30 Partial Dissenting Opinion of Judge Weinberg De Roca, para. 41, Blaškić (IT-95-14-A), Appeals Chamber, 29 July 2004.

31 Some judgments take the position that ordering implies the existence of a superior-subordinate relationship between the individual who gives the order and the one who executes it, Akayesu (ICTR-964-T), 2 September 1998, para. 483; Semanza (ICTR-97-20-T), 15 May 2003, para. 382, citing with approval Bagilishema (ICTR-95-1A-T), 7 June 2001, para. 30. Other Chambers hold the opinion that a formal superior-subordinate is not a requirement for a finding of 'ordering' as a form of criminal participation , see Kajelijeli (ICTR-98-44A-T), 1 December 2003, para. 763; Kordić \& Čerkez (IT-9514/2-T), 26 February 2001, para. 388; Strugar (IT-01-42-T), 31 January 2005, para. 331.

32 Limaj (IT-03-66), 30 November 2005, para. 515, citing Brđanin (IT-99-36-T), 1 September 2004, para. 270; Gacumbitsi (ICTR-2001-64-T), 17 June 2004, para. 282.

33 Gacumbitsi (ICTR-2001-64-T), 17 June 2004, para. 283.

34 Galić (IT-98-29-S), 30 March 2004, para. 168, citing Krstić (IT-98-33-T), 2 August 2001, para. 601; Akayesu (ICTR-96-4), 2 September 1998, para. 483; Blaškić (IT-95-14-T), 3 March 2000, para. 281; Kordić and Čerkez (IT-95-14/2-T), 26 February 2001, para. 388.

35 Strugar (IT-01-42-T), 31 January 2005, para. 331, citing Blaškić (IT-95-14-T), 3 March 2000, para. 281; Kordić and Čerkez (IT-95-14/2-T), 26 February 2001, para. 388. Galić (IT-98-29-S), 30 March 2004, para. 171. See also the Final Report of the Commission of Experts established pursuant to Security Council Resolution 780 (1992), 27 May 1994 (S/1994/674) at 17.

36 Strugar (IT-01-42-T), 31 January 2005, para. 332. In Gacumbtsi, the ICTR found that the accused incurred liability for having ordered the policemen to kill the Tutsi, since the participation of those policemen was a direct consequence of the orders given by the accused, Gacumbitsi (ICTR-200164-T), 17 June 2004, para. 284.

37 Strugar (IT-01-42-T), 31 January 2005, para. 332.

38 Blaškić (IT-95-14-A), Appeals Chamber, 29 July 2004.

39 Blaškić (IT-95-14-A), Appeals Chamber, 29 July 2004, para. 41 (emphasis added).

40 Blaškić (IT-95-14-A), Appeals Chamber, 29 July 2004, para. 42. Limaj (IT-03-66), 30 November 2005, para. 515; Kordić and Čerkez (IT-95-14/2-A), Appeals Chamber, 17 December 2004, para. 30; Brđanin (IT-99-36-T), 1 September 2004, para. 270.

41 Blaškić (IT-95-14-T), 3 March 2000, para. 592.

42 Blaškić (IT-95-14-T), 3 March 2000, para. 282.

43 Kajelijeli (ICTR-98-44A-T), 1 December 2003, para. 769.

44 Kunarac (IT-96-23/1-T), 22 February 2001, para. 391. 
45 On this point see Orić (IT-03-68-T), 30 June 2006, para. 280.

46 Several judgments rendered by the Rwanda Tribunal defined aiding to mean 'giving assistance to someone' and abetting to involve 'facilitating the commission of an act by being sympathetic thereto'; see Akayesu (ICTR-96-4), 2 September 1998, para. 484; Kayishema (ICTR-95-1-T), 21 May 2001, para. 196; Ntakirutimana [(ICTR-96-10-T) and (ICTR-96-17-T)], 21 February 2003, para. 787. Concerning abetting in particular, the Semanza Trial Chamber refers to it as 'encouraging, advising or instigating the commission of a crime': Semanza (ICTR-97-20-T), 15 May 2003, para. 384. Other cases further include 'facilitating' as well; see Kajelijeli (ICTR-98-44A-T), 1 December 2003, para. 765; Kamuhanda (ICTR95-54A-T), 22 January 2004, para. 596. See also Limaj (IT-03-66), 30 November 2005, para. 516.

47 Muhimana (ICTR-95-1B-T), 28 April 2005, para. 507; Gacumbitsi (ICTR-2001-64-T), 17 June 2004, para. 286; Ntakirutimana [(ICTR-96-10-T) and (ICTR-96-17-T)], 21 February 2003, para. 787; Semanza (ICTR-97-20-T), 15 May 2003, para. 384; Kajelijeli (ICTR-98-44A-T), 1 December 2003, para. 763; Kvočka (IT-98-30/1-T), 2 November 2001, para. 254.

48 Blagojević (IT-02-06-T), 17 January 2005, para. 726; Brđanin (IT-99-36-T), 1 September 2004, para. 271; Tadić (IT-94-1-A), Appeals Chamber, 15 July 1999, para. 229; Aleksovski (IT-95-14/1-A), Appeals Chamber, 24 March 2000, paras. 163-164; Čelebići (IT-96-21-A), Appeals Chamber, 20 February 2001, para. 352; Furundžija (IT-95-17/1-T), 10 December 1998, paras. 235, 249; Vasiljević (IT-98-32-A), Appeals Chamber, 25 February 2004, para. 102; Naletilić (IT-98-34-T), 31 March 2003, para. 63; Simić (IT-95-9-T), 17 October 2003, para. 161. In Tadić, the Appeals Chamber held that the principal offender may not even be aware of the accomplice's contribution: Tadić (IT-94-1-A), Appeals Chamber, 15 July 1999, para. 229.

49 Akayesu (ICTR-96-4-T), 2 September 1998, para. 473-475; Aleksovski (IT-95-14/1-A), Appeals Chamber, 24 March 2000, para. 165; Blagojević (IT-02-06-T), 17 January 2005, para. 726; Brđanin (IT-99-36-T), 1 September 2004, para. 271.

50 Orić (IT-03-68-T), 30 June 2006, para. 283; Kvoćka (IT-98-30/1-T), 2 November 2001, para. 257; Krnojelac (IT-97-25-T), 15 March 2002, para. 89;Vasiljević (IT-98-32-T), 29 November 2002, para. 70; Limaj (IT-03-66), 30 November 2005, para. 517.

51 Orić (IT-03-68-T), 30 June 2006, para. 283.

52 Orić (IT-03-68-T), 30 June 2006, para. 284; Vasiljević (IT-98-32-A), Appeals Chamber, 25 February 2004, para. 102; Blagojević (IT-02-06-T), 17 January 2005, para. 726; Furundžija (IT-95-17/1-T), 10 December 1998, paras 223-24, 249; Aleksovski (IT-95-14/1-T), 25 June 1999, para. 61; Kunarac (IT-9623/1-T), 22 February 2001, para. 391; Kordić and Čerkez (IT-95-14/2-T), 26 February 2001, para. 399; Vasiljević (IT-98-32-T), 29 November 2002, para. 70. The Kajelijeli Trial Chamber stated as follows: 'Such act of assistance before or during the fact need not have actually caused the consummation of the crime by the actual perpetrator, but it must have had a substantial effect on the commission of the crime by the actual perpetrator', Kajelijeli (ICTR-98-44A-T), 1 December 2003, para. 766.

53 Kamuhanda (ICTR-95-54A-T), 22 January 2004, para. 597; Blagojević (IT-02-06-T), 17 January 2005, para. 726; Blaškić (IT-95-14-A), Appeals Chamber, 29 July 2004, para. 165; Čelebići (IT-96-21-A), Appeals Chamber, 20 February 2001, para. 352; Blagojević (IT-02-60-A), Appeals Chamber, 9 May 2007, para. 127.

54 Blagojević (IT-02-06-T), 17 January 2005, para. 731.

55 Blagojević (IT-02-06-T), 17 January 2005, para. 731; Blagojević (IT-02-60-A), Appeals Chamber, 9 May 2007, paras 177-181.

56 Orić (IT-03-68-T), 30 June 2006, para. 286.

57 Vasiljević (IT-98-32-A), Appeals Chamber, 25 February 2004, para. 102; Blaškić (IT-95-14-A), Appeals Chamber, 29 July 2004 paras. 46, 49-50;Aleksovski (IT-95-14/1-A), Appeals Chamber, 24 March 2000, para. 162; Tadić (IT-94-1-A), Appeals Chamber, 15 July 1999, para. 229; Brđanin (IT-99-36-T), 1 September 2004, para 272; Kajelijeli (ICTR-98-44A-T), 1 December 2003, para. 768; Kayishema (ICTR-95-1-A), Appeals Chamber, 1 June 2001, paras 186-187; Semanza (ICTR-97-20-T), 15 May 2003, para. 387; Bagilishema (ICTR-95-1A-T), 7 June 2001, para. 32. This awareness need not have been explicitly expressed, it may be inferred from all relevant circumstances, see Limaj (IT-03-66), 30 November 2005, para. 518.

58 Aleksovski (IT-95-14/1-A), Appeals Chamber, 24 March 2000, para. 162; Blagojević (IT-02-06-T), 17 January 2005, para. 727; Krnojelac (IT-97-25-T), 15 March 2002, para. 90.

59 Orić (IT-03-68-T), 30 June 2006, para. 288; In Blaskic, as in Begilishema, the Trial Chamber required that the aider and abettor 'intended to provide the assistance, or as a minimum, accepted that such assistance would be a possible and foreseeable consequence of his conduct', in addition to requiring knowledge 
that the conduct of the accused assisted and facilitated the commission of the crim€." see Blaškic (IT-95-14-T), 3 March 2000, para. 286; Bagilishema (ICTR-95-1A-T), 7 June 2001, para. 32.

60 Orić (IT-03-68-T), 30 June 2006, para. 288 (emphasis added, footnotes omitted).

61 Limaj (IT-03-66), 30 November 2005, para. 518; Aleksovski (IT-95-14/1-A), Appeals Chamber, 24 March 2000, para. 162; Krnojelac (IT-97-25-T), 15 March 2002, para. 90.

62 Limaj (IT-03-66), 30 November 2005, para. 518, citing Blaskić (IT-95-14-A), Appeals Chamber, 29 July 2004 , para. 50.

63 Schabas, The UN International Criminal Tribunals, pp. 306-37.

64 Limaj (IT-03-66), 30 November 2005, para. 509; Krstić (IT-98-33-A), Appeals Chamber, 19 April 2004, para. 188; Kunarac (IT-96-23/1-T), 22 February 2001, para. 390; Gacumbitsi (ICTR-2001-64-T), 17 June 2004, para. 285.

65 Kajelijeli (ICTR-98-44A-T), 1 December 2003, para. 764.

66 It is to be noted that unlike the ICC Statute, the Statutes of the ICTY and the ICTR lack a provision concerning 'intermediary perpetration', in which the accused, as an indirect perpetrator, uses another innocent person as his or her instrument to perform the relevant conduct.

67 Limaj (IT-03-66), 30 November 2005, para. 509, citing Kordić and Čerkez (IT-95-14/2-T), 26 February 2001, para. 376

68 Galić (IT-98-29-S), 30 March 2004, para. 136.

69 See Kvočka (IT-98-30/1-A), Appeals Chamber, 28 February 2005, paras 79-80, 99; Tadić (IT-94-1-A), Appeals Chamber, 15 July 1999, paras 188, 195-226; Milutinović et al. (IT-99-37-AR72), Decision in Dragoljub Ojdanić's Motion Challenging Jurisdiction - Joint Criminal Enterprise, 21 May 2003, para. 20;Vasiljević, (IT-98-32-A) Appeals Chamber, 25 February 2004, para. 111; Ntakirutimana (ICTR-9617-A), Appeals Chamber, 13 December 2004, para. 462; Karemera et al. (ICTR-98-44-T), Decision on Jurisdictional Appeals: Joint Criminal Enterprise, Appeals Chamber, 12 April 2006, para. 16.

70 Tadić (IT-94-1-A), Appeals Chamber, 15 July 1999, para. 191; Furundžija (IT-95-17/1-T), 10 December 1998, para. 256.

71 A. Cassese, 'The Proper Limits of Individual Responsibility under the Doctrine of Joint Criminal Enterprise', Journal of International Criminal Justice 5, 2007, 109-133, 110.

72 JCE has been a source of endless fascination for commentators, generating an enormous amount of literature. A. O'Rourke, 'Joint Criminal Enterprise and Brđanin: Misguided Over-Correction', Harvard International law Journal 47, 2006, 307; A. Danner and J. Martinez, 'Guilty Associations: Joint Criminal Enterprise, Command Responsibility, and the Development of International Law', California Law Review 93, 2005, 75; K. Ambos, 'Joint Criminal Enterprise and Command Responsibility', Journal of International Criminal Justice 5, 2007, 159; M. Elewa Badar, “Just Convict Everyone!'”Joint Perpetration: From Tadić to Stakić and Back Again', International Criminal Law Review 6, 2006, 293; J. Ohlin, 'Three Conceptual Problems with the Doctrine of Joint Criminal Enterprise', Journal of International Criminal Justice 5, 2007, 69; K. Gustafson, 'The Requirement of an "Express Agreement" for Joint Criminal Enterprise Liability: A Critique of Brđanin', Journal of International Criminal Justice 5, 2007, 134; H. van der Wilt, 'Joint Criminal Enterprise, Possibilities and Limitations', Journal of International Criminal Justice 5, 2007, 91; E. van Sliedregt, 'Pathway to Convicting Individuals for Genocide', Journal of International Criminal Justice 5, 2007, 184.

73 Stakić (IT-97-24-A), Appeals Chamber, 22 March 2006, para. 64; Kvočka (IT-98-30/1-A), Appeals Chamber, 28 February 2005, paras. 82-83;Vasiljević (IT-98-32-A), Appeals Chamber, 25 February 2004, paras. 96-99; Krnojelac (IT-97-25-A), Appeals Chamber, 17 September 2003, para. 30; Simba (ICTR01-76-T), 13 December 2005, para. 386. It is worth pointing out that while joint criminal enterprise liability has been firmly established in the jurisprudence of the ICTY since the Tadić Appeal Judgment in 1999, the ICTR was first called upon to address the issue in two cases in 2004. See André Rwamakuba (ICTR-98-44-AR72.4), Decision on Interlocutory Appeal Regarding Application of Joint Criminal Enterprise to the Crime of Genocide, 22 October 2004, and Ntakirutimana (ICTR-96-17-A), Appeals Chamber, 13 December 2004.

74 The Krnojelac Appeals Chamber held that 'using the concept of joint criminal enterprise to define an individual's responsibility for crimes physically committed by others requires a strict definition of common purpose', Krnojelac (IT-97-25-A), Appeals Chamber, 17 September 2003, para. 116

75 Stakić (IT-97-24-A), Appeals Chamber, 22 March 2006, para. 64; Kvočka (IT-98-30/1-A), Appeals Chamber, 28 February 2005, para. 96; Ntakirutimana (ICTR-96-17-A), Appeals Chamber, 13 December 2004, para. 466; Vasiljević (IT-98-32-A), Appeals Chamber, 25 February 2004, para. 100; Krnojelac (IT-97-25-A), Appeals Chamber, 17 September 2003, para. 31; Simba (ICTR-01-76-T), 13 December 
2005, para. 386; Brđjanin (IT-99-36-T), Decision on Motion for Acquittal Pursuant to Rule 98 bis, 28 November 2003, para. 26.

76 Krnojelac (IT-97-25-A), Appeals Chamber, 17 September 2003, para. 81.

77 Krajišnik (IT-00-39-A), Appeals Chamber, 17 March 2009, para. 156; Limaj et al. (IT-03-66-A), Appeal Judgment, 27 September 2007, para. 99.

78 Brđanin (IT-99-36-A), Appeals Chamber, 3 April 2007, para. 418; Krajišnik (IT-00-39-A), Appeals Chamber, 17 March 2009, para. 163.

79 Krajišnik (IT-00-39-A), Appeals Chamber, 17 March 2009, para. 163.

80 Krajišnik (IT-00-39-A), Appeals Chamber, 17 March 2009, para. 185.

81 Tadić (IT-94-1-A), Appeals Chamber, (15 July 1999), para. 196; Krnojelac (IT-97-25-A), Appeals Chamber, 17 September 2003, para. 84; Ntakirutimana (ICTR-96-17-A), Appeals Chamber, 13 December 2004, para. 467.

82 Tadić (IT-94-1-A), Appeals Chamber, 15 July 1999, para. 196; Vasiljević (IT-98-32-A), Appeals Chamber, 25 February 2004, para. 97; Ntakirutimana (ICTR-96-17-A), Appeals Chamber, 13 December 2004, 463.

83 Tadić (IT-94-1-A), Appeals Chamber, 15 July 1999, para. 196.

84 This argument was raised by the Amicus Curiae in their Notice of Appeal in the Krajišnik case. See Krajišnik (IT-00-39-A), Appeals Chamber, 17 March 2009, para. 220, quoting the Amicus Curiae's Notice of Appeal, para. 50

85 Krajišnik (IT-00-39-A), Appeals Chamber, 17 March 2009, para. 225, quoting Brđanin (IT-99-36-A), Appeals Chamber, 3 April 2007, para 413.

86 Kvočka (IT-98-30/1-A), Appeals Chamber, 28 February 2005, paras 99, 112; Tadić (IT-94-1-A), Appeals Chamber, 15 July 1999, para. 192.

87 Tadić (IT-94-1-A), Appeals Chamber, 15 July 1999, para. 228.

88 Kvočka (IT-98-30/1-A), Appeals Chamber, 28 February 2005, para. 82; Tadić (IT-94-1-A), Appeals Chamber, 15 July 1999, paras 202-203; Krnojelac (IT-97-25-A), Appeals Chamber, 17 September 2003, para. 89: ('The Appeals Chamber holds that, although the second category of cases defined by the Tadic Appeals Judgment "systemic" clearly draws on the Second World War extermination and concentration camp cases, it may be applied to other cases and specially to the serious violations of international humanitarian law committed in the territory of the former Yugoslavia since 1991'); Kvočka (IT-98-30/1-T), 2 November 2001, para. 202.

89 Cassese, 'The Proper Limits', p. 112.

90 Kvočka (IT-98-30/1-A), Appeals Chamber, 28 February 2005, para. 96.

91 Krajišnik (IT-00-39-A), Appeals Chamber, 17 March 2009, para. 675; Brđanin (IT-99-36-A), Appeals Chamber, 3 April 2007, para. 430; Kvočka (IT-98-30/1-A), Appeals Chamber, 28 February 2005, para. 97.

92 Kvočka (IT-98-30/1-A), Appeals Chamber, 28 February 2005, para. 599.

93 Ibid.

94 Krnojelac (IT-97-25-A), Appeals Chamber, 17 September 2003, paras 89, 96.

95 Kvočka (IT-98-30/1-A), Appeals Chamber, 28 February 2005, para. 110.

96 Krnojelac (IT-97-25-A), Appeals Chamber, 17 September 2003, paras 118-124.

97 Ibid., para. 122.

98 Ibid.

99 Stakić (IT-97-24-A), Appeals Chamber, 22 March 2006, para. 87.

100 Stakić (IT-97-24-T), 31 July 2003, para. 530

101 Bardanin (IT-99-36-T), Decision on Motion for Acquittal Pursuant to Rule 98 bis, 28 November 2003, para. 57.

102 Ibid.

103 Barđanin (IT-99-36-A), Decision on Interlocutory Appeal, 19 March 2004, paras 5-10.

104 Tadić (IT-94-1-A) Appeals Chamber, 15 July 1999, para. 229.

105 The term 'just convict everyone' was used by Professor William Schabas as an alternative to the third category of JCE during a lecture at the fifth annual International Criminal Court Summer Course in Galway in 2005 hosted by the Irish Centre for Human Rights, National University of Galway, Ireland. See Badar, 'Just Convict Everyone'.

106 Stakić (IT-97-24-T), 31 July 2003, paras. 438-441. The Stakić Trial Chamber applied a combination of two forms of commission, known in German criminal law as Mittäterschaft (co-perpetration) and mittelbare Täterschaft (indirect perpetratorship); for more information on joint principles in German 
Criminal Law see M. Bohlander, General Principles of German Criminal Law, Oxford: Hart Publishing, 2009, pp. 161-66.

107 Stakić (IT-97-24-T), 31 July 2003, para. 440.

108 Ibid.

109 Stakić (IT-97-24-T), 31 July 2003, para. 440, quoting Claus Roxin, Täterschaft und Tatherrschaft, Berlin, New York, 1994, 278.

110 Stakić (IT-97-24-T), 31 July 2003, paras 495-497.

111 See Badar, “Just Convict Everyone!”.

112 Halilović (IT-01-48-T), 16 November 2005, para. 55, citing Čelebići (IT-96-21-A), Appeals Chamber, 20 February 2001, para. 195; Čelebići (IT-96-21-T), 16 November 1998, para. 343; Strugar (IT-0142-T), 31 January 2005, para. 357.

113 Čelebići (IT-96-21-A), Appeals Chamber, 20 February 2001, para. 197; Kordić and Čerkez (IT-9514/2-T), (26 February 2001), para. 369; Kayishema (ICTR-95-1-T), 21 May 1999, para. 217; Musema (ICTR-96-13-T), 27 January 2000, para. 148.

114 Halilović (IT-01-48-T), 16 November 2005, para. 54. For more details on omission as a culpable conduct, see M. Duttwiller, 'Liability for Omission in International Criminal Law', International Criminal Law Review 6, 2006, 1-61.

115 There is a consensus in the jurisprudence of the ICTY and ICTR that the doctrine of command responsibility extends beyond the responsibility of military commanders to encompass civilian superiors in positions of authority; see Bagilishema (ICTR-95-1A-T), 7 June 2001, paras 41-43;

116 Orić (IT-03-68-T), 30 June 2006, para. 294. See also Ntagerura (ICTR-99-46-T), 25 February 2004, para. 627; Semanza (ICTR-97-20-T), 15 May 2003, para. 400; Blaškić (IT-95-14-A), Appeals Chamber, 29 July 2004, para. 484; Aleksovski (IT-95-14/1-A), Appeals Chamber, 24 March 2000, para. 72.

117 Orić (IT-03-68-T), 30 June 2006, para. 297, referring to the Defence Final Brief, para. 507 et seq., and the Defence Closing Argument, T. 16438.

118 Boškoski and Tarčulovski (IT-04-82-PT), Decision on Prosecution's Motion to Amend the Indictment, 26 May 2006, paras 18-48.

119 Orić (IT-03-68-T), 30 June 2006, para. 302.

120 Ibid., para. 305.

121 Ibid., para. 304.

122 Limaj (IT-03-66), 30 November 2005, para. 521; Strugar (IT-01-42-T), 31 January 2005, para. 359.

123 Ntagerura (ICTR-99-46-T), 25 February 2004, para. 628; Halilović (IT-01-48-T), 16 November 2005, para. 58; Galić (IT-98-29-S), 30 March 2004, para. 173.

124 Čelebići (IT-96-21-A), Appeals Chamber, 20 February 2001, para. 256. See also Blaškić (IT-95-14-A), Appeals Chamber, 29 July 2004, para. 69.

125 Blaškić (IT-95-14-A), Appeals Chamber, 29 July 2004, para. 69.

126 Orić (IT-03-68-T), 30 June 2006, para 311; Ntagerura (ICTR-99-46-T), 25 February 2004, para. 628; Semanza (ICTR-97-20-T), 15 May 2003, para. 402.

127 Čelebići (IT-96-21-T), 16 November 1998, paras 353-354, 370, 736, confirmed by Čelebići (IT-9621-A), Appeals Chamber, 20 February 2001, paras 195 et seq;Aleksovski (IT-95-14/1-T), 25 June 1999, para. 76; Blaškić (IT-95-14-T), 3 March 2000, para. 301; Kunarac (IT-96-23/1-T), 22 February 2001, para. 396; Kordić and Čerkez (IT-95-14/2-T), 26 February 2001, para. 416; Naletilić (IT-98-34-T), 31 March 2003, para. 67; Stakić (IT-97-24-T), 31 July 2003, para. 459; Halilović (IT-01-48-T), 16 November 2005, paras. 58, 60; Musema (ICTR-96-13-T), 27 January 2000, para. 148; Kayishema (ICTR-95-1-T), 21 May 1999, paras. 218, 222.

128 Orić (IT-03-68-T), 30 June 2006, para. 310.

129 Ibid., para. 318; Čelebići (IT-96-21-A), Appeals Chamber, 20 February 2001, para. 239; Čelebići (IT-96-21-T), 16 November 1998, para. 383; Halilović (IT-01-48-T), 16 November 2005, para. 65; Brđanin (IT-99-36-T), 1 September 2004, para. 278; Blagojević (IT-02-06-T), 17 January 2005, para. 792; Kajelijeli (ICTR-98-44A-T), 1 December 2003, para. 776.

130 Limaj (IT-03-66), 30 November 2005, para. 523; Halilović (IT-01-48-T), 16 November 2005, para. 64; Ntagerura (ICTR-99-46-T), 25 February 2004, para. 629.

131 Ntagerura (ICTR-99-46-T), 25 February 2004, para. 629; Semanza (ICTR-97-20-T), 15 May 2003, para. 405; Halilović (IT-01-48-T), 16 November 2005, para. 65.

132 Orić (IT-03-68-T), 30 June 2006, para. 317.

133 Barđanin (IT-99-36-A), Decision on Interlocutory Appeal, 19 March 2004, para. 7.

134 Kordić and Čerkez (IT-95-14/2-T), 26 February 2001, para. 427. 
135 K. Keith, 'The Mens Rea of Superior Responsibility as Developed by ICTY Jurisprudence', Leiden Journal of International Law 14, 2001, 617-34, 619.

136 Bagilishema (ICTR-95-1A-A), Appeals Chamber, 3 July 2002, paras 34-35; Blaškić (IT-95-14-A), Appeals Chamber, 29 July 2004, para. 63; Halilović (IT-01-48-T), 16 November 2005, para. 71.

137 Kordić and Čerkez (IT-95-14/2-T), 26 February 2001, para. 371.

138 Čelebići (IT-96-21-T), 16 November 1998, para. 386; Trial Judgment, para. 524; Halilović (IT-0148-T), 16 November 2005, para. 66; Aleksovski (IT-95-14/1-T), 25 June 1999, para. 80; Blaškić (IT-9514-T), 3 March 2000, para. 308. The Aleksovski and Blaškić Judgments indicated that the position of authority of the superior over the subordinate may in some circumstances of itself be an indicator that the superior must have known of the subordinate's conduct. Kayishema (ICTR-95-1-T), 21 May 1999, para. 225.

139 Limaj (IT-03-66), 30 November 2005, para. 524; Kordić and Čerkez (IT-95-14/2-T), 26 February 2001, para. 427; Blaškić (IT-95-14-T), 3 March 2000, para. 307; Strugar (IT-01-42-T), 31 January 2005, para. 368.

140 Bagilishema (ICTR-95-1A-A), Appeals Chamber, 3 July 2002, para. 28.

141 Halilović (IT-01-48-T), 16 November 2005, para. 68.

142 Strugar (IT-01-42-T), 31 January 2005, para. 416.

143 Blaškić (IT-95-14-A), Appeals Chamber, 29 July 2004, para. 406 (emphasis in original).

144 Čelebići (IT-96-21-A), Appeals Chamber, 20 February 2001, paras 223 and 241; Brđanin (IT-9936-T), 1 September 2004, para. 278; Halilović (IT-01-48-T), 16 November 2005, para. 68; Galić (IT-98-29-S), 30 March 2004, para. 175.

145 Final Report of the Commission of Inquiry into the Events at the Refugee camps in Beirut, 7 February 1983 (Kahan Report), reproduced in 22 International Legal Materials (1983) 473-520, cited by Halilović (IT-01-48-T), 16 November 2005, fn. 164 and Blaškić (IT-95-14-T), 3 March 2000, paras 330-331.

146 Blaškić (IT-95-14-T), 3 March 2000, para. 331, citing the Kahan Report.

147 Blaškić (IT-95-14-T), 3 March 2000, para. 331, citing the Kahan Report (emphasis added). See also Halilović (IT-01-48-T), 16 November 2005, fn. 164. See also L. Malone, 'Kahan Report, Ariel Sharon and the Sabra-Shatila Massacres in Lebanon; Responsibility under International Law for Massacres of Civilian Populations, 1985 Utah Law Review, 373.

148 Čelebići (IT-96-21-A), Appeals Chamber, 20 February 2001, para. 226; Blaškić (IT-95-14-A), Appeals Chamber, 29 July 2004, para. 62; Halilović (IT-01-48-T), 16 November 2005, para. 69.

149 Čelebići (IT-96-21-A), Appeals Chamber, 20 February 2001, para. 226, endorsed by Blaškić (IT-9514-A), Appeals Chamber, 29 July 2004, para. 62.

150 Halilović (IT-01-48-T), 16 November 2005, para. 69.

151 Bagilishema (ICTR-95-1A-T), 7 June 2001, para. 897.

152 Blaškić (IT-95-14-A), Appeals Chamber, 29 July 2004, para. 63, citing Bagilishema (ICTR-95-1A-A), Appeals Chamber, 3 July 2002, paras 34-35.

153 Bagilishema (ICTR-95-1A-A), Appeals Chamber, 3 July 2002, para. 35; Blaškić (IT-95-14-A), Appeals Chamber, 29 July 2004, para. 63; Orić (IT-03-68-T), 30 June 2006, para. 324; Halilović (IT-01-48-T), 16 November 2005, para. 71.

154 Orić (IT-03-68-T), 30 June 2006, para. 324.

155 Orić (IT-03-68-T), 30 June 2006, para. 326.

156 Blaškić (IT-95-14-T), 3 March 2000, para. 336.

157 Schabas, The UN International Criminal Tribunals, p. 320.

158 Ibid.

159 Orić (IT-03-68-T), 30 June 2006, para. 277.

160 See Blaškić (IT-95-14-A), Appeals Chamber, 29 July 2004, para. 41; Orić (IT-03-68-T), 30 June 2006, para. 279.

161 Model Penal Code and Commentaries: Official Draft and Revised Comments, Philadelphia: The American Law Institute, 1980 \2.06 Comment at 312, fn. 42.

162 See Blaškić (IT-95-14-A), Appeals Chamber, 29 July 2004, para. 41.

163 Clayton v. The Queen, [2006] High Court of Australia 58, para. 108. 
